\title{
Induction and transfer of resistance to poisoning by Amorimia pubiflora in sheep whith non-toxic dosis of the plant and ruminal content
}

\author{
Indução e transferência de resistência à intoxicação por Amorimia pubiflora \\ em ovinos com doses não tóxicas de planta e conteúdo ruminal
}

\author{
Marciel Becker ${ }^{I^{*}}$ Faber Monteiro Carneiro $^{\mathrm{I}}$ Leonardo Pintar de Oliveira ${ }^{\mathrm{II}}$ \\ Mayara Inácio Vincenzi da Silva ${ }^{\text {II }}$ Franklin Riet-Correa ${ }^{\text {III }}$ Stephen Thomas Lee ${ }^{\text {IV }}$ \\ Caroline Argenta Pescador $^{\mathrm{V}}$ Luciano Nakazato $^{\mathrm{V}}$ Edson Moleta Colodel $^{\mathrm{V}}$
}

\section{ABSTRACT}

Amorimia pubiflora (Malpighiaceae), which contains sodium monofluoroacetate (MFA) is the main cause of "sudden death" in cattle in the Brazilian state of Mato Grosso. This research investigated the induction of resistance to the poisoning in sheep by the continuous administration of non-toxic doses of the plant and also the possibility to transfer this resistance to other sheep by the transfaunation of ruminal fuid. For this a group of four sheep (G1) received daily doses of $0.5 \mathrm{~g} \mathrm{~kg}^{-1}$ for 20 days and after an interval of 15 days were challenged with three daily doses of $1 \mathrm{~g} \mathrm{~kg}^{-1}$ for 3 days. Also the transfer of resistance to A. pubiflora poisoning was evaluated by transfaunation of rumen fluid (100ml for 10 days) from G1 sheep to five sheep (G2), followed by challenge with the dose of $1 \mathrm{~g} \mathrm{kg-1}$ for 3 days (G2D2) and after a three-day interval they received a single dose of $3 \mathrm{~g} \mathrm{~kg}^{-1}$ (G2D3). The degree of resistance was evaluated by monitoring the onset of clinical signs, heart rate, and outcome of the poisoning compared with the control groups, which were challenged with three daily doses of $1 \mathrm{~g} \mathrm{~kg}^{l}$ (G3) and with a single dose of $3 \mathrm{~g} \mathrm{~kg}^{-1}$ (G4). Clinical parameters evaluated in Groups G1 and G2 were significantly less pronounced than those observed in $G 3$ and $G 4$ (control) $(P<0.05)$. Sheep in $G 4$ (control) died after receiving a single dose of $3 \mathrm{~g} \mathrm{~kg}^{-1}$, while those in G2 (transfaunated) survived. These findings demonstrated that consumption of non-toxic doses of A. pubiflora induced resistance in sheep and that this resistance can be transferred by transfaunation. New experiments are needed to determine the most efficient ways to induce resistance and to use this technique in the field to prevent the poisoning.
Key words: Mascagnia pubiflora, monofluoroacetate, ruminal detoxification, sheep, sudden death, toxic plants.

\section{RESUMO}

Amorimia pubiflora (Malpighiaceae) contém monofluoroacetato de sódio (MFA) e é uma das principais causas de "morte-súbita" em bovinos no estado de Mato Grosso, no Brasil. Este trabalho investiga a indução de resistência à intoxicação por A. pubiflora em ovinos, através da administração repetida de doses não tóxicas, e também se é possivel transferir essa resistência para outros ovinos por transfaunação do fluido ruminal. Para a indução à resistência, um grupo com quatro ovinos (G1) recebeu doses diárias individuais de $0,5 \mathrm{~g} \mathrm{~kg}^{-1}$ de folhas de A. pubiflora durante 20 dias. Após um intervalo de 15 dias, os ovinos desse grupo foram desafiados diariamente, durante 3 dias consecutivos, com a dose de $1 \mathrm{~g} \mathrm{~kg}^{-1}$. A transferência de resistência à intoxicação por A. Pubiflora foi avaliada por transfaunação de conteúdo ruminal (100ml diariamente durante 10 dias) do G1, para cinco ovinos (G2). Após essa etapa, os cinco ovinos do Grupo G2 receberam a dose de $1 \mathrm{~g} \mathrm{~kg}^{-1}$ por três dias (G2D2) e, após um intervalo de 3 dias, quatro ovinos do G2 receberam uma única dose de $3 g \mathrm{~kg}^{-1}$ (G2D3). O grau de resistência foi conferido mediante o monitoramento do início dos sinais clínicos, frequência cardiaca, desfecho da intoxicação e comparação com grupos controle, os quais foram desafiados com três doses repetidas de ${\operatorname{lg~} \mathrm{kg}^{-1}}^{-1}(\mathrm{G} 3) \mathrm{e}$ uma dose única de $3 \mathrm{~g} \mathrm{~kg}^{-1}(\mathrm{G} 4)$. Os parâmetros clínicos avaliados nos Grupos G1 e G2 foram significativamente menos evidentes do que os observados nos G3 e G4 (controles) $(P<0,05)$. Os ovinos

'Programa de Pós-graduação em Ciências Veterinárias, Faculdade de Agronomia e Medicina Veterinária, Universidade Federal de Mato Grosso (UFMT), Avenida Fernando Corrêa da Costa, 2367, 78068-900, Cuiabá, MT, Brasil. E-mail: marcielbecker@hotmail.com. ${ }^{*}$ Corresponding author.

"Departamento de Medicina Veterinária, Faculdade de Agronomia e Medicina Veterinária, Universidade Federal de Mato Grosso (UFMT), Cuiabá, MT, Brasil.

"I'Hospital Veterinário, Centro de Saúde e Tecnologia Rural, Universidade Federal de Campina Grande (UFCG), Campus de Patos, Patos, PB, Brasil.

IV Poisonous Plant Research Laboratory, Agricultural Research Service, United States Department of Agriculture, 1150 E. 1400 N., Logan, UT 84341, USA.

${ }^{\vee}$ Departamento de Clínica Médica Veterinária, Faculdade de Agronomia e Medicina Veterinária, Universidade Federal de Mato Grosso (UFMT), Cuiabá, MT, Brasil. 
do G4 (controle) morreram após receber a dose única de $3 \mathrm{~g} \mathrm{~kg}^{-1}$, enquanto os do G2 (transfaunados) sobreviveram. Esses achados indicam que o consumo de doses não tóxicas de A. pubiflora induz resistência em ovinos e que a resistência pode ser transferida por transfaunação. Novos experimentos são necessários para determinar as formas mais práticas para induzir resistência e a forma de usar essa técnica no campo para controlar a intoxicação por essa planta.

Palavras-chave: Mascagnia pubiflora, morte súbita, microbiota ruminal, monofluoracetato, plantas tóxicas.

\section{INTRODUCTION}

In Brazil the group of toxic plants of greatest importance to livestock is that causing "sudden death", including Palicourea spp., Amorimia spp., Tanaecium (Arrabidaea) bilabiatum, Fridericia (Arrabidaea) japurensis, and Pseudocalymma elegans (LEE et al., 2012; TOKARNIA et al., 2012). Sodium monofluoracetate (MFA) has been identified in most of these species (LEE et al., 2012).

Amorimia pubiflora (A. Juss.) W.R. Anderson (ANDERSON, 2006) popularly known as "corona", "suma" or "cipó-prata" is one of the most important toxic plants in the Midwest region of Brazil (FERNANDES \& MACRUZ, 1964; TOKARNIA \& DOBEREINER, 1973; SANTOS, 1975; BECKER et al., 2013). The plant also occurs in the Northeastern region (state of Bahia) and Southeastern region (states of Minas Gerais, São Paulo, Goiás, and Rio de Janeiro) (MAMEDE, 2010). Leaves of $\boldsymbol{A}$. pubiflora deposited in the University of Michigan Herbarium contained $0.006 \%$ of MFA (LEE et al., 2012), and leaves from sprouting plants collected in the municipality Colniza, state of Mato Grosso, contained $0.015 \%$ MFA (BECKER et al., 2013).

Several outbreaks of $A$. pubiflora poisoning have been reported in cattle in the states of Mato Grosso do Sul and Mato Grosso. Rates of morbidity and mortality were up to $3.5 \%$ and $54.5 \%$, respectively. The disease is characterized by "suddendeath" associated with exercise. The main clinical signs are weakness, engorged jugular vein, slight muscle tremors, and muscle contractions, followed by death in a $5-15$ minutes period (TOKARNIA \& DOBEREINER, 1973; LEMOS et al., 2011; BECKER et al., 2013). In the state of Mato Grosso, in some municipalities of the Amazon region A. pubiflora is the main cause of cattle losses (TOKARNIA et al., 2012; BECKER et al., 2013).

Reports that cattle coming from regions where are no MFA-containing plants are more susceptible to poisoning suggest that the animals become resistant to the consumption of MFAcontaining plants (SILVA et al., 2008; BECKER et al., 2013). This could be related to fluoroacetate dehydrogenase activity of ruminal micro-organisms which break the carbon-fluorine bond degrading the MFA (FETZNER \& LINGENS, 1994). Several MFA-degrading microorganisms have been isolated from soil in Australia (TWIGG \& SOCHA, 2001) and Brazil (CAMBOIM et al., 2012a) and from ruminal content of goats (CAMBOIM et al., 2012b) and cattle (PIMENTEL, 2011) in Brazil. Goats ingesting daily non-toxic doses of $\boldsymbol{A}$. septentrionalis increased significantly their resistance to the poisoning by this MFA-containing plant (DUARTE et al., 2013).

The objectives of these experiments were to investigate if the daily administration of non-toxic doses of $\boldsymbol{A}$. pubiflora in sheep induces resistance to the poisoning by this plant, and to determine if this resistance can be transferred by transfaunation of rumen fluid to susceptible sheep.

\section{MATERIALS AND METHODS}

Amorimia pubiflora leaves used in this study were collected in the city of Colniza, MT $\left(09^{\circ} 25^{\prime} 76^{\prime \prime S}-59^{\circ} 03\right.$ '55"W) on days 14/11/2011, $19 / 12 / 2011$ and 08/06/2012. Botanical identification was performed by Dr. William R. Anderson (University of Michigan Herbarium, Ann Arbor, Michigan, USA) and a voucher specimen of the plant was authenticated and deposited in the Herbarium of Michigan University, Michigan, USA (LEE et al., 2012). The MFA content of the $\boldsymbol{A}$. pubiflora leaves was $0.015 \%$ (BECKER et al., 2013).

\section{Experimental animals}

The experiment was performed with 16 Santa Inês, 1-2 years-old, clinically healthy female sheep raised under confinement in the Experimental Sheep Farm of the UFMT in the municipality of Santo Antônio de Leverger, state of Mato Grosso (MT). All sheep have been dewormed 7-10 days before the start of the experiment and divided at random into four groups (two treated and two controls). Each group was kept in $9 \mathrm{~m}^{2}$ bays at the Veterinary Hospital of the Universidade Federal de Mato Grosso (UFMT), Cuiabá, MT. All animals were weighed prior to the supply of $\boldsymbol{A}$. pubiflora to calculate the dose of the plant to be administered. Most sheep consumed leaves of $\boldsymbol{A}$. pubiflora voluntarily and when this did not happen, the leaves were orally administered by repeatedly inserting small amounts into the mouths of the animals. The experiment with the number of 
animals, doses and $\boldsymbol{A}$. pubiflora administration period in each group are shown in table 1.

Group 1 (induction of resistance by $\boldsymbol{A}$. pubiflora administration)

To induce resistance to $\boldsymbol{A}$. pubiflora poisoning the four sheep (\#1, 2, 3 and 4) received daily $0.5 \mathrm{~g} \mathrm{~kg}^{-1}$ of $\boldsymbol{A}$. pubiflora leaves during 20 consecutive days. Amorimia pubiflora administration was interrupted when clinical signs of moderate intensity were observed, especially when the heart rate (HR) was above $130 \mathrm{bpm}$ when the sheep was resting, or above $200 \mathrm{bpm}$ after the movement, or when the animal remained lying for a prolonged time after plant administration. The administration was restarted when the HR was less than $80 \mathrm{bpm}$ with sheep at rest.

Following the induction phase, the sheep from this group spent 15 days without ingesting $\boldsymbol{A}$. pubiflora. Then, they were challenged by the ingestion of $1 \mathrm{~g} \mathrm{~kg}^{-1}$ daily for three days. Subsequently, to verify the duration of resistance to the consumption of $\boldsymbol{A}$. pubiflora, sheep \#3 was challenged with a single dose of $3 \mathrm{~g} \mathrm{~kg}^{-1}$ on day 166 , and again with the dose of $5 \mathrm{~g}$ $\mathrm{kg}^{-1}$ on day 180 .

Group 2 (transfaunated)

One day after the end of the challenge $100 \mathrm{~mL}$ of rumen content was collected daily, with

Table 1 - Onset and intensity of clinical signs and outcome of the poisoning by Amorimia pubiflora in sheep with resistance induced by the daily administration of $\boldsymbol{A}$. pubiflora (G1) or by transfaunation (G2) and in control sheep (G2 and G4). Data from G1 correspond to the induction phase and to challenge. Data from G2, G3, and G4 correspond to the induction phase and to challenge. Data from G2, G3, and G4 correspond to challenge.

\begin{tabular}{|c|c|c|c|c|c|}
\hline Group (Phase) & Sheep \# & Daily dose $\left(\mathrm{g} \mathrm{kg}^{-1}\right)$ & Number of doses & Intensity of clinical signs & Outcome \\
\hline \multirow{7}{*}{ G1 (Induction of Resistance) } & \multirow{2}{*}{1} & \multirow{7}{*}{0,5} & \multirow{7}{*}{20} & NCS & \multirow{2}{*}{$\mathrm{R}$} \\
\hline & & & & NCS & \\
\hline & \multirow{2}{*}{2} & & & Moderate & \multirow{2}{*}{$\mathrm{R}$} \\
\hline & & & & Moderate & \\
\hline & \multirow{2}{*}{3} & & & Moderate & \multirow{2}{*}{$\mathrm{R}$} \\
\hline & & & & Moderate & \\
\hline & 4 & & & $\mathrm{NCS}$ & $\mathrm{R}$ \\
\hline \multirow{4}{*}{ G1 Challenge 1/D1 } & 1 & \multirow{4}{*}{1,0} & \multirow{4}{*}{3} & Light & $\mathrm{R}$ \\
\hline & 2 & & & \multirow{2}{*}{ Discrete } & $\mathrm{R}$ \\
\hline & 3 & & & & $\mathrm{R}$ \\
\hline & 4 & & & Discrete & $\mathrm{R}$ \\
\hline \multirow{5}{*}{ G2 (transfauned) First challenge } & 5 & \multirow{5}{*}{1,0} & \multirow{5}{*}{3} & Discrete & $\mathrm{R}$ \\
\hline & 6 & & & NCS & $\mathrm{R}$ \\
\hline & 7 & & & Discrete & $\mathrm{R}$ \\
\hline & 8 & & & NCS & $\mathrm{R}$ \\
\hline & 9 & & & NCS & $\mathrm{R}$ \\
\hline \multirow{4}{*}{ G2 (transfauned) Second challenge } & 5 & \multirow{4}{*}{3,0} & \multirow{4}{*}{1} & Discrete & $\mathrm{R}$ \\
\hline & 7 & & & NCS & $\mathrm{R}$ \\
\hline & 8 & & & Discrete & $\mathrm{R}$ \\
\hline & 9 & & & Discrete & $\mathrm{R}$ \\
\hline \multirow{3}{*}{ G3 (Control 1) } & 10 & \multirow{3}{*}{1,0} & \multirow{3}{*}{3} & Moderate & $\mathrm{R}$ \\
\hline & 11 & & & Moderate & $\mathrm{R}$ \\
\hline & 12 & & & Moderate & $\mathrm{R}$ \\
\hline \multirow{4}{*}{ G4 (Control 2) } & 13 & \multirow{4}{*}{3,0} & \multirow{4}{*}{1} & Severe & $\mathrm{D}$ \\
\hline & 14 & & & Severe & $\mathrm{D}$ \\
\hline & 15 & & & FD & $\mathrm{D}$ \\
\hline & 16 & & & Severe & $\mathrm{D}$ \\
\hline
\end{tabular}

NCS: No clinical signs; FD: it was found dead; R: clinical recovery; D: Death.

Ciência Rural, v.46, n.4, abr, 2016. 
a ruminal tube, during 10 days, from each sheep of Group 1 and transferred by gavage to five sheep (\#5, $6,7,8$ and 9) from Group 2 at the dose of $100 \mathrm{ml}$ daily for each sheep. One day after the end of the transfaunation period the sheep from Group 2 were challenged with a dose of $1 \mathrm{~g} \mathrm{~kg}^{-1}$ daily during three consecutive days (D2) and after a three-day interval four sheep (\#5, 7, 8 and 9) they received a single dose of $3 \mathrm{~g} \mathrm{~kg}^{-1}$ (D3).

\section{Control groups}

Two control groups were used: G3 (Sheep \#10, 11 and 12), which received $A$. pubiflora at the dose of $1 \mathrm{~g} \mathrm{~kg}^{-1}$ daily for three consecutive days; and G4 (sheep \#13, 14, 15 and 16), which received $3 \mathrm{~g} \mathrm{~kg}^{-1}$ of $\boldsymbol{A}$. pubiflora in a single dose.

\section{Statistical analysis}

Data analyzes were performed using the software R Development Core Team (2012) (PAULA, 2004). To find the difference between groups used the regression range (PAULA, 2004) with the linear predictor $(\eta)$ and the logarithmic function $\eta=\ln \left(\mu_{i}\right)$.

\section{Clinical follow-up}

During the phases of resistance induction and challenge, clinical observations were performed three to four times a day in all sheep prior to and after the plant administration. Examination consisted on the observation of pulsations, respiratory and ruminal movements, behavior, posture and water and food intake. Six to eight hours after the plant administration the animals were forced to run for 10 minutes and pulsation and respiratory movements were determined before and after exercise.

Resistance of G1 and G2 sheep to the consumption of $\boldsymbol{A}$. pubiflora was compared with the resistance of control groups by evaluating the variation of heart rate, outcome of the clinical picture and the start and intensity of clinical signs, which were classified as: severe (marked tachycardia, above $180 \mathrm{bpm}$, engorged jugular, venous pulse, cardiac arrhythmia, muscle tremors, kyphosis, stiff gait, apathy, head tremor, mandibular trismus, reluctance to move, circling, cyanosis, sudden falls and convulsions, followed by death); moderate (moderate tachycardia, 130-180bpm, jugular engorgement, venous pulse, cardiac arrhythmia, apathy, reluctance to move, sudden falls, with clinical recovery); mild (mild tachycardia, 100130bpm, kyphosis, stiff gait and apathy); and discrete (only tachycardia, below $80 \mathrm{bpm}$ ).
Pathology

Sheep that died were necropsied. Fragments of lymph nodes, intestines, rumen, reticulum, omasum, abomasum, pancreas, adrenal, urinary bladder, kidney, thyroid, heart, lung, and brain were collected and fixed in $10 \%$ formalin and processed routinely in the Veterinary Pathology Laboratory of the Veterinary Hospital UFMT for histopathological analysis.

\section{RESULTS}

The amount $\boldsymbol{A}$. pubiflora ingested by sheep from group 1 during the induction of resistance and by sheep from groups 1, 2, 3, and 4 during challenge as well as the severity of clinical signs and the outcome of the poisoning are presented in table 1. The mean heart rates during the period of administration of $\boldsymbol{A}$. pubiflora and the average time between the start of administration and the first signs are shown in figure 1.

In group 1 during the resistance induction period two sheep showed moderate clinical signs. In sheep 2 showed clinical signs $93 \mathrm{~h}$ and $286 \mathrm{~h}$ after the start of administration. In both occasions, the administration was suspended and restarted after 74 and $60 \mathrm{~h}$ later, respectively. In sheep 3 the administration was suspended $119 \mathrm{~h}$ and $262 \mathrm{~h}$ after the start of ingestion and restarted $47 \mathrm{~h}$ and $133 \mathrm{~h}$ later.

During challenge, the mean time to the observation of first clinical signs of the G1 (resistant) $(89 \mathrm{~h} 27 \mathrm{~min} \pm 15 \mathrm{~h} 32 \mathrm{~min})$ was significantly higher than that of G3 (control) (23h15 min $\pm 00 \mathrm{~h} 37 \mathrm{~min})(\mathrm{P}<0.05)$. The average value of heart rate (HR) of the G1 (resistant), (77 $\pm 14 \mathrm{bpm})$ was significantly lower than the HR of the G3 (control) (126 $\pm 25 \mathrm{bpm})(\mathrm{P}<0.05)$. The period of observation of the first clinical signs of the $\mathrm{G} 2$ sheep after the first challenge with the administration of $1 \mathrm{~g} \mathrm{~kg}^{-1}$ during three days (100h47min $\pm 11 \mathrm{~h} 48 \mathrm{~min}$ ) and after the second challenge with one dose of $3 \mathrm{~g} \mathrm{~kg}^{-1}$ $(29 \mathrm{~h} 44 \mathrm{~min} \pm 10 \mathrm{~h} 13 \mathrm{~min})$ were significantly higher than those of controls groups G3 $(23 \mathrm{~h} 15 \mathrm{~min} \pm 00 \mathrm{~h} 37 \mathrm{~min})$ and G4 (13h10min \pm 03 h06min $)(P<0.05)$. There were no significant differences between the values of $\mathrm{HR}$ in group 2 during the challenge with $1 \mathrm{~g} \mathrm{~kg}^{-1}$ daily during three days $(84 \pm 17 \mathrm{bpm})$ and the challenge with $3 \mathrm{~g} \mathrm{~kg}^{-1}$ in one administration $(119 \pm 57 \mathrm{bpm})$. But the HR was significantly higher $(\mathrm{P}<0.05)$ in the control groups: $126 \pm 25 \mathrm{bpm}$ in G3, and $176 \pm 17 \mathrm{bpm}$ in G4. The four sheep from Group 4 (control) died when challenged with a single dose of $3 \mathrm{~g} \mathrm{~kg}^{-1}$, while the sheep from G2 sheep (transfauned) challenged with the same dose survived. Sheep 3 from this group were 


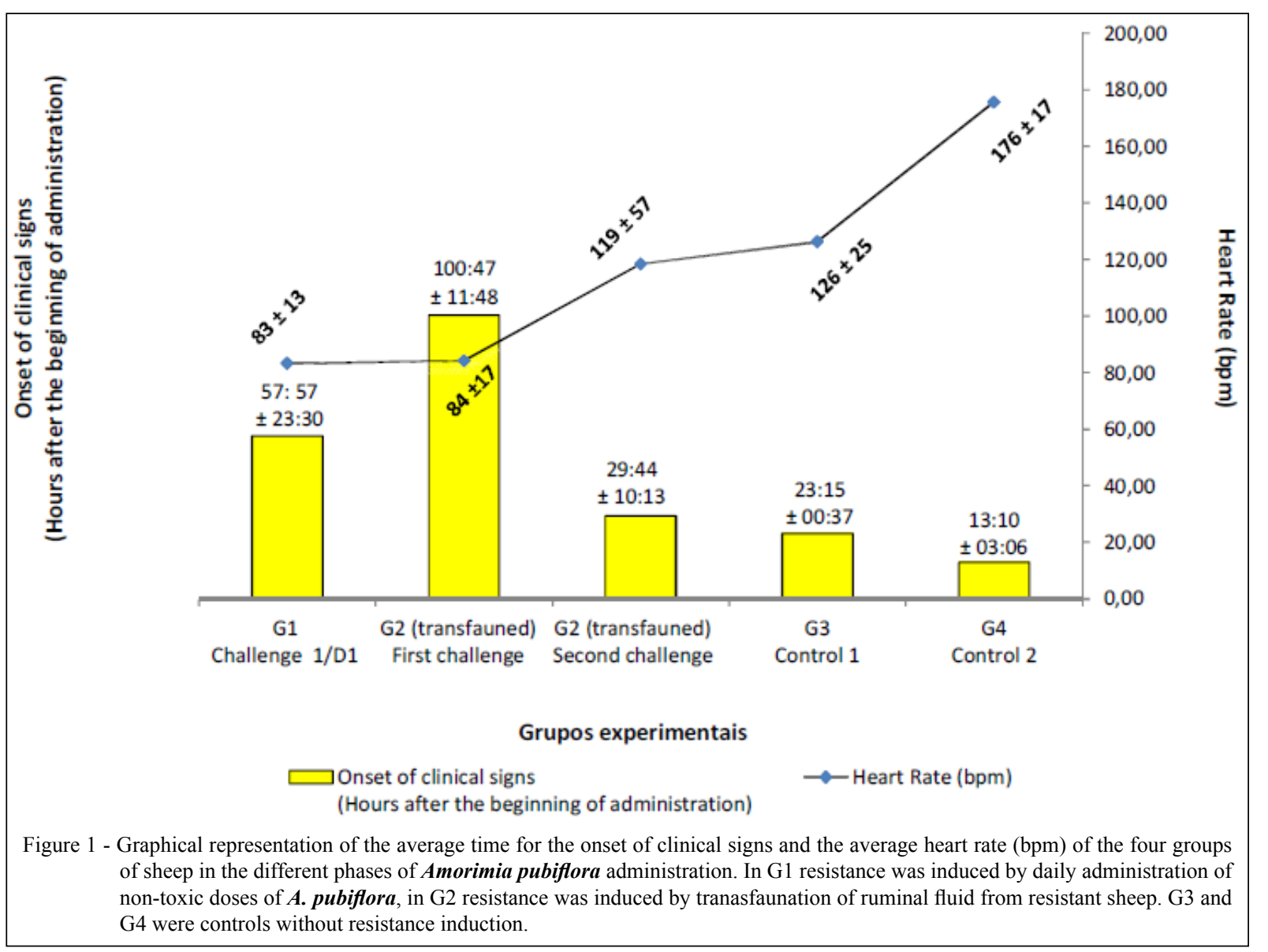

challenged with a single dose of $3 \mathrm{~g} \mathrm{~kg}^{-1} 166$ days after the end of the experiment also survived, but died when challenged with a single dose of $5 \mathrm{~g} \mathrm{~kg}^{-1}$ two weeks later.

\section{DISCUSSION}

Results of this experiment demonstrated that the daily intake of non-toxic doses of $\boldsymbol{A}$. pubiflora to sheep increases the resistance to poisoning by this plant. They also demonstrated that this resistance can be transferred by transfaunation of rumen fluid from resistant sheep to susceptible sheep that never ingested $\boldsymbol{A}$. pubiflora. Similar results were obtained by DUARTE et al. (2013) who demonstrated an increase in the resistance to poisoning by $\boldsymbol{A}$. septentrionalis in goats after the repeated ingestion of non-toxic doses of this plant and also that this resistance may be transferred by transfaunation of ruminal fluid to susceptible goats.

Farmers from Colniza, MT reported that cattle coming from regions where "sudden death" did not occurwere more susceptible to $A$. pubiflora poisoning, which can be an indication that the animals become resistant to the consumption of MFA-containing plants (BECKER et al., 2013). Another possibility is that the higher resistance is due to the death of the more susceptible animals in the areas where MFA-containing plants occurred. Similar observations report that animals grazing in areas with $A$. rigida are more resistant to poisoning than those kept in areas without this plant (SILVA et al., 2008).

Resistance has been related with the presence of ruminal MFA-degrading microorganisms in the rumen, which contain a dehydrogenase enzyme that breaks the carbon-fluorine bond, producing fluorine and glycolate (FETZNER \& LINGENS, 1994). Thirteen fungi and 11 bacteria that degrade MFA were isolated from soil samples in Australia (TWIGG \& SOCHA, 2001). In the state of Paraíba seven MFA-degrading bacteria were isolated from soil or plants (CAMBOIM et al., 2012a) and two were isolated from the rumen of goats (CAMBOIM et al., 2012b). In the state of Mato Grosso, two MFA-degrading bacteria, Enterococcus faecalis and Bacillus sp., were isolated from the rumen content of cattle (PIMENTEL, 2011). In Australia a 
genetically modified ruminal bacteria, Butyrivibrio fibrisolvens, was used to increase resistance to MFA poisoning (GREGG et al., 1998). The increase of the resistance to $\boldsymbol{A}$. pubiflora by the continuous administration of small doses of this plant and the transference of the resistance to other sheep by the transfaunation of ruminal fluid indicated that MFAdegrading bacteria may be normal inhabitants of the ruminal flora and that the ingestion of non-toxic doses of MFA-containing plants stimulates their multiplication (CAMBOIM et al., 2012b).

These results showed that the increase of resistance conferred by the ingestion of non-toxic doses of MFA-containing plants, transfaunation of rumen fluid from resistant animals, and intraruminal inoculation of MFA-degrading bacteria (PESSOA et al. 2015) may be used to prevent poisoning by MFA-containing plants. However, these possibilities should be considered along with other alternatives, such as the knowledge of the epidemiology of the poisoning, chemical or mechanical control of the plant, and the restriction on the use areas with the presence of the plants. In Mato Grosso, manual removal or chemical control of A. pubiflora in the pastures and the use of fences to isolate the affected areas has not been effective because the plant has deep taproots, which predisposes the regrowth, and is generally present in all pastures.

Survival of sheep 3 challenged, 166 days after the induction of the lethal toxic dose of $3 \mathrm{~g} \mathrm{~kg}^{-1}$, indicates a possibility of durable resistance to this period. However, the death of this sheep, 14 days after, with the dose of $5 \mathrm{~g} \mathrm{~kg}^{-1}$ suggested that despite a significant increase in resistance the animals remain susceptible to high doses of the plant. New experiments are needed to determine the most efficient ways to induce resistance and to use this technique in the field to prevent the poisoning.

\section{CONCLUSION}

The results of this experiment demonstrated that the daily intake of non-toxic single doses of $\boldsymbol{A}$. pubiflora increases the resistance of sheep to the poisoning by this plant and that resistance can be transferred by transfaunation of rumen content from resistant to susceptible sheep.

\section{BIOETHICS AND BIOSECURITY COMMITTEE APPROVAL}

This study was approved by ETHICS IN ANIMAL USE COMMITTEE (CEUA) of the Universidade Federal de Mato Grosso (UFMT), through the process number 23108.014901/11-7 of May 13, 2011.

\section{ACKNOWLEDGEMENTS}

The National Institute of Science and Technology for Poison Control for Plants - Process 0573534-2008-0 for funding this project, Dr William R. Anderson for botanical identification.

\section{REFERENCES}

ANDERSON, W.R. Eight segregates from the neotropical genus Mascagnia (Malpighiaceae). Novon, v.16, n.2, p.168-204, 2006. Available from: <http://herbarium.lsa.umich.edu/malpigh/ MALPpdf/N16-8newgen.pdf>. Accessed: Sept. 13, 2013.

BECKER, M. et al. The importance of poisoning by Amorimia pubiflora (Malpighiaceae) in cattle in Mato Grosso: experimental reproduction of the poisoning in sheep and cattle. Pesquisa Veterinária Brasileira, v. 33, n.9, p.1049-1056, 2013. Available from: <http://www.pvb.com.br/pdf_artigos/12-10-2013 1140Vet\%201459_3207\%20LD.pdf $>$. Accessed: Oct. 13, 2013.

CAMBOIM, K.A. et al. Defluorination of sodium fluoroacetate by bacteria from soil and plants in Brazil. Scientific World Journal, v.2012, p.1-5, 2012a. Available from: <http://www.ncbi.nlm.nih. gov/pmc/articles/PMC3349100/>. Accessed: Feb. 04, 2013. doi: $10.1100 / 2012 / 149893$.

CAMBOIM, K.A. et al. Isolation and identification of sodium fluoroacetate degrading bactéria from caprine rumen in Brazil. Scientific World Journal, v.2012, p. 1-6, 2012b. Available from: $<$ http://www.ncbi.nlm.nih.gov/pmc/articles/PMC3417187/>. Accessed: Feb. 09, 2013. doi: 10.1100/2012/178254.

DUARTE, A.L.L. et al. Induction and transfer of resistance to poisoning by Amorimia (Mascagnia) septentrionalis in goats. Journal of Applied Toxicology, v.34, p.220-223, 2013. Available from: <http://www.ncbi.nlm.nih.gov/pubmed/23400835>. Accessed: Nov. 10, 2013. doi: 10.1002/jat.2860.

FERNANDES, N.S.; MACRUZ, R. Toxicidade da "corona" Mascagnia pubiflora (Juss.) Griseb. (Malpighiaceae). Arquivos do Instituto Biológico Animal, v.31, p.1-4, 1964.

FETZNER, S.; LINGENS, F. Bacterial dehalogenases: biochemistry, genetics, and biotechnological applications. Microbiological Reviews, v.58, n.4, p.641-685, 1994. Available from: <http://www. ncbi.nlm.nih.gov/pubmed/7854251>. Accessed: Feb. 04, 2013.

GREGG, K. et al. Genetically modified ruminal bacteria protect sheep from fluoroacetate poisoning. Applied and Environmental Microbiology, v.9, p.3496-3498, 1998. Available from: <http://aem.asm.org/content/64/9/3496.full. pdf $>$. Accessed: Feb. 06, 2013.

LEE, S.T. et al. Detection of monofluoroacetato in Palicourea and Amorimia species. Toxicon, v.60, p.791-796, 2012. Available from: <http://www.ncbi.nlm.nih.gov/pubmed/22699106>. Accessed: Mar. 01, 2013. doi: 10.1016/j.toxicon.2012.05.029.

LEMOS, R.A.A. et al. Plant poisonings in Mato Grosso do Sul. In: RIET-CORREA, F. et al. Poisoning by plants, mycotoxins, and related toxins. Cambridge, MA: CAB International, 2011. Cap.11, p.68-72.

MAMEDE, M.C.H. Amorimia in lista de espécies da flora do Brasil. Jardim Botânico do Rio de Janeiro. Available from: 
$<$ http://floradobrasil.jbrj.gov.br/jabot/floradobrasil/FB101438>. Accessed: Jan. 07, 2015.

PAULA, G.A. Modelos de regressão com apoio computacional, 2004. IME/USP R Development Core Team (2012). R: A language and environment for statistical computing. $\mathrm{R}$ Foundation for Statistical Computing. Vienna, Austria, 2012. ISBN 3-900051-070 . Available from: $<$ https://www.ime.usp.br/ giapaula/texto_2013. pdf $>$. Accessed: Mar. 01, 2013.

PESSOA D.A.N. et al. Resistance to poisoning by Amorimia septentrionalis in goats induced by ruminal inoculation of the bacteria Pigmentiphaga kullae and Ancylobacter dichloromethanicus. Pesquisa Veterinária Brasileira, v.35, n.2, p.125-128, 2015. Available from: <http://www.scielo.br/pdf/pvb/v35n2/0100-736Xpvb-35-02-00125.pdf $>$. Accessed: Mar. 03, 2015.

PIMENTEL, M.F.A. Isolamento e identificação de microrganismo resistente ao fluoroacetato de sódio. 2011. $42 \mathrm{f}$. Dissertação (Mestrado em Medicina Veterinária) - Programa de Pós-graduação em Ciências Veterinárias, Universidade Federal de Mato Grosso, MT.

SANTOS, H.L. Aspectos clínicos, laboratoriais e anatomohistopatológicos na intoxicação experimental de bovinos pela Mascagnia rigida. 1975. 36f. Dissertação (Mestrado em Medicina Veterinária) - Curso de Pós-graduação em Medicina Veterinária, Universidade Federal de Minas Gerais, MG.

SILVA, P. et al. Poisoning by Mascagnia rigida (Malpighiaceae) leaves in sheep Comunicação científica. Arquivos do Instituto Biológico Animal, v.75, n.2, p.229-233, 2008. Available from: $<$ http://www.biologico.sp.gov.br/docs/arq/v75_2/silva.pdf $>$. Accessed: Feb. 04, 2013.

TOKARNIA, C.H.; DÖBEREINER, J. Intoxicação por Mascagnia pubiflora em bovinos no Estado de Mato Grosso. Pesquisa Agropecuária Brasileira, v.8, p.61-68, 1973 Available from: <file://C:/Users/marciel/Downloads/17373-75069-1-SM.pdf>. Accessed: Feb. 04, 2013.

TOKARNIA, C.H. et al. Plantas tóxicas do Brasil. 2.ed. Rio de Janeiro: Helianthus, 2012. 566p.

TWIGG, L.E.; SOCHA, L.V. Defluorination of sodium monofluoroacetate by soil microorganisms from central Australia. Soil Biology \& Biochemistry, v.33, p.227-234, 2001. Available from: <http://www.sciencedirect.com/science/article/pii/ S0038071700001346>. Accessed: Feb. 06, 2013. doi: 10.1016/ S0038-0717(00)00134-6. 